\title{
The Impact of 'Democratization in the Context of the EU Accession Process' on Turkish Foreign Policy
}

\author{
TARIK OGUZLU
}

\begin{abstract}
This essay analyses the process, style and outcome dimensions of Turkish foreign policy in the 1990s in the light of the 'democratization alongside the European Union [EU] accession process'. Two possible independent variables are compared and contrasted: the democratization process per se and the democratization as taking place within the context of Turkey's Europeanization process. The main questions addressed are: in which ways has Turkey's democratization alongside the EU accession process impacted on Turkey's foreign policy and why has the increasing quality of Turkish democratization per se not produced pro-EU Turkish foreign policy outcomes in relation to the Cyprus and European Security and Defence Policy (ESDP) issues.
\end{abstract}

This essay will analyse the process (multi-actor or uni-actor), style (bullying or compromising) and outcome dimensions (pro-European Union [EU] or anti-EU) of Turkish foreign policy in the 1990s in the light of the so-called 'democratization alongside the European Union accession process' [Iokimidis, 2000: 359-72]. In undertaking this task, the essay will place special emphasis on two issue-areas, namely the disputes over Cyprus and the European Security and Defence Policy (ESDP). The novelty of this approach lies in its attempt to compare and contrast two possible independent variables in this regard, namely the democratization process per se and the democratization as taking place within the context of Turkey's Europeanization process.

While the first process can theoretically occur independently of Turkey's relationship with the EU, the second can never be thought of as taking place independently of Turkey's Europeanization process, viz. Turkey's march to EU membership. The crucial point with respect to the second process is that here the general quality of Turkey's relations with the EU, particularly the nature of Turkey-EU security relations, would affect the promise of this process. While the label of transitional democracy can better represent Turkey's national identity when viewed from the first perspective, Turkey can be defined as a democratizing country alongside the Europeanization process when viewed from the second perspective.

Tarik Oguzlu teaches in the Department of International Relations at Bilkent University, Ankara.

Mediterranean Politics, Vol.9, No.1 (Spring 2004), pp.94-113

ISSN 1362-9395 print

DOI: $10.1080 / 13629390410001679946$ C 2004 Taylor \& Francis Ltd. 
This essay mainly seeks answers to two crucial questions: in which ways Turkey's democratization alongside the EU accession process has impacted on Turkey's foreign policy and why the increasing quality of Turkish democratization per se has not produced pro-EU (European Unionoriented) Turkish foreign policy outcomes on the above-mentioned issues.

The essay will proceed in the following way. First, a theoretical background will be provided in order to establish the conceptual differences and linkages between these two processes and Turkish foreign policy. Here the tool kit of constructivist approaches will help us depict these linkages. The emphasis will be both on the impacts of identities of states on their foreign policy choices and on the role of socially constructed international and domestic structures in the construction of states' identities, interests and foreign policy behaviour.

The second part will succinctly examine the impacts of these two processes on Turkish foreign policies up to the end of the cold war. What is of significant value here is the way the traditional Kemalist state elites tended to interpret/define/construct democratization process per se and democratization alongside Europeanization process. To what extent did Turkey's Europeanization process include Turkey's democratization?

In the third section the main goal will be to analyse the challenges of the 1990s to the attempts at understanding Turkey's foreign policy practices. The question will be why it has become gradually more difficult to delineate the differences between these two processes as they have gradually become constitutive of each other. The major premise of this part is that it is the dynamics of the democratization alongside the Europeanization process, rather than the dynamics of the democratization process per se, that could better explain Turkey's foreign policy outcomes. A subsection will put this analysis within the context of the ongoing debate between the Eurosceptic and pro-EU circles in Turkey. The question will be how these circles have interpreted these two processes. The fourth section will weigh the impact of these processes against Turkey's foreign policies vis-à-vis the Cyprus and ESDP issues. The conclusion will recap the findings of the research.

\section{Theoretical Background}

There are two theoretical linchpins of this essay. The first is that there is a close relationship between identities of states and their foreign policy interests and behaviour. Whether a state is 'democratic' or not, 'democratizing' or not, 'European' or not, 'Europeanizing' or not, and so on, will certainly matter as far as the foreign policy orientation of that state is concerned [Walker, 1993; Wendt, 1999].

Based on the tool kit of the constructivist approaches, the democratic peace theory holds that the more democratized states become, the more 
peaceful and co-operative their foreign policy behaviour towards other democracies would become. Their tendency to utilize peaceful methods of conflict resolution would increase. The increasing weight of public opinion, the establishment of institutional checks and balances and the internalization of democracy norms would all dictate more cautious, more rational, more co-operative and less costly outcomes. Democratization is considered here as a process. A more democratizing state would take the utmost care to develop co-operative relationships with other democracies wherever they are located. In such polities, the capabilities of power holders, or the current governments, to reconstruct their domestic identities through foreign policy practices would diminish in the long run as numerous societal actors would actively participate in the foreign policymaking process and retain their chances to legitimately come to power via elections [Risse-Kappen, 1995: 491-517; Ray, 1998: 27-46; Flynn and Farrell, 1999: 505-36].

Those who subscribe to this view mainly hold that the degree of Turkey's co-operative relationships with the EU countries would go in parallel to the degree of Turkey's democratization. To them a more democratic Turkey would in turn adopt a more compromising style, a more multidimensional process and more EU-oriented outcomes. In the long term, as the country gradually becomes more democratized, the participation of various societal groups in the foreign policy-making process would lead to the adoption of more rational and more co-operative attitudes towards other democracies.

In case Turkey adopts a more bullying style, a more unilateral process and more anti-EU foreign policy outcomes, the analysts of this type would attribute the reasons to the ongoing democratization process per se in Turkey [Tsakonas, 2001: 1-40]. The depiction of Turkey as a transitional democracy would help them examine better the country's choices in general and the attitudes of different societal sections in particular. In this logic, the current power holders would instinctively adopt more nationalistic and less co-operative policies abroad and tend to securitize as many issues as possible with a view to upholding/reconstructing their image as the guardian and protector of national security interests in an environment of hostile states. In response to the challenges coming from opposition groups, both within and outside the country, a nationalistic turn in foreign policy would seem to be the only alternative for the power holders to reclaim their eroding legitimacy in the eyes of the people in the short term [Tsakonas, 2001: 1-40]. In this logic, the democratization process can operate independently of the external environment.

The second theoretical linchpin of this essay is that the democratization alongside the EU accession process and the process of democratization per se 
may not need always to overlap with one another, particularly in the context of such EU candidate states as Turkey [Olsen, 2002: 921-52]. Even though the former shares with the latter many common points, the dynamics of the first are somehow different from the dynamics of the second. It is the contention of this essay that one had better name the first as an outcome rather than a process. There are two main reasons for this. The first is the fact that democratization along the EU accession process aims not only at the establishment of democratic regimes in candidate states but also at the internalization of the EU's identity. Being a democratic European country would imply that candidate states should formulate and implement foreign policies in harmony with the identity and interests of the EU. Here the direction of candidate states' foreign policies needs to be established towards the EU, as the latter demands the aspirant countries to do so.

The second reason concerns the fact that the EU here constitutes one of the external stimuli/inputs in the establishment of democracies in candidate countries. In one way or another, the EU can be considered as a party involved in this process. The way it gets involved in this process would not only affect the prospects of democratization in candidate states but also their abilities to adapt to the EU's foreign policy identity and interests.

It must be noted here that the real success of the democratization along the EU accession process in such EU candidates as Turkey would be contingent on the nature/quality of relations between these states and the EU. Here the likelihood that candidate states follow EU-oriented foreign policies would be dependent on the successful implementation of the democratization along the EU accession process. The more this process proceeds smoothly, the more easily they would follow EU-friendly foreign policies. All these have to do with perceptions. The questions of "whether the EU fully supports the Europeanization processes of candidate states by offering them promising rewards and costly punishments'; 'whether the parties consider each other as security threats or security providers'; 'whether the EU is seriously and wholeheartedly encouraging the pro-EU local circles in their attempts at adopting the EU's norms and rules'; 'whether the EU provides them with clear timetables for eventual accession backed by detailed programmes aimed at the acceleration of the membership process'; and 'whether candidate states fully share in the idea that the most appropriate thing for them would be to do what the European Union requires in the accession criteria' are really important in this regard [Smith, 2000: 33-46; Grabbe, 2002: 249-68]. In this case, the democratization process itself and its impact on foreign policies would be strongly tied to the dynamics of relations with the EU. 


\section{Prior to the 1990 s}

Since the establishment of the Turkish Republic in 1923, the motto of Turkish foreign policy has been 'peace at home, peace abroad'. Even though a direct interpretation of this saying seems to imply that the founders of the Republic set in motion a democratization programme in the liberalpluralist sense, this was not the case at all. Rather, the ruling elites of the country stuck to the nineteenth-century positivist understanding of this phrase [Heper, 2000: 63-82].

In this logic, the main democratizing agent would have to be the state and the extent of the democratization process would have to be defined by the state, in a top-down manner, in accordance with the requirements of Kemalist ideology. Democratization per se was not included among the six principles of the Kemalist creed. Since the Ottoman Empire had come to an end owing to its multinational and religious undertones, the first job of the republican elites had been to establish 'secularism and homogenous nationalism' as the guiding principles of the new state [Heper, 2000: 63-82].

The first thing to do in this process would have been to establish friendly relations with the old enemies of the Ottoman Empire. Thought of this way, the 'Europeanization' process was somehow perceived as a kind of 'survival strategy' by the founders of the Republic. The logic was instrumental in that if the major European powers respected Turkey's territorial borders and avoided interfering in Turkey's domestic affairs, the republican elites would find a suitable atmosphere in which to successfully implement their own visions within the country. If the republican elites had been sure that Turkey and the major European powers perceived each other as 'security providers' instead of 'security threats', then their domestic political programmes might have gone uninterrupted with the possibility of foreign interference in Turkey's domestic affairs eliminated [Oguzlu, 2002a: 579-603]. It is within this context that Turkey happily sided with the European powers within NATO (North Atlantic Treaty Organization) against the collective communist threat in the North.

The bipolar nature of cold war politics also enabled the Kemalist elites to easily follow a Europe-oriented foreign policy, though the level and quality of democratization within the country was not acceptable by the European standards. The Europeans did not question Turkey's 'Europeanness' even though Turkey departed from the democracy track many times during the cold war. The logic of security co-operation overwhelmed the logic of democratic peace [Dagi, 2001: 51-68]. Democratization as understood by the EU following the cold war did not constitute one of the indispensable elements of the 'Europeanization' process that had existed 
during much of the cold war era itself. Neither did the European powers ask Turkey to democratize more as a precondition for Turkey's equal standing with EC (European Community) members within NATO, as well as for the continuation of Turkey's institutional relationship with the EC, nor did Turkey display any further desire to back up its 'hard-security cooperation with the European powers' by adopting the EC members' conception of democracy. Thus, the dynamics of Turkey's democratization process have mainly remained independent of the dynamics of Turkey's relations with the EC/EU. It seems that the nature and quality of Turkey's security relations with the EU, defined in terms of externally defined common security interests and falling short of strict EC/EU demands on Turkey to democratize, could better explain Turkey's pro-Europe foreign policy during this era than the democratization process per se.

One significant reason for the EC not to criticize Turkey severely for its poor record on the democratization process emanated from its cold war international identity. The EC was more inter-governmental, more statecentric, less democracy and human rights oriented, less politically oriented, more economy driven and more strategic-security sensitive [Aybet and Müftüler-Baç, 2000: 567-82].

The Kemalist state elites interpreted the ongoing democratization efforts in Turkey as a process and defined it along the modernization path. The involvement of the EC members as external parties to this process was out of the question during much of this era, except for the EC members' decision to freeze Turkey's associate membership in the wake of the 1980 military coup.

Paradoxically, to some extent the democratization process contributed to the solidification of the power base and legitimacy of the Kemalist state elites in the eyes of the Turkish people, for two main reasons. The first is that in the absence of active European involvement in Turkey's democratization, the state elites defined themselves as the main agents of democratization within the country. Both they and the majority of the people saw the state elites as the true agents of Turkey's democratization efforts. The second is that these elites had the opportunity to reconstruct their identities as the true democratizers and Europeanizers as they saved the country from further chaos and anarchy caused by the misbehaviour of politicians.

However, when the EC members accelerated the process of integration in the second half of the $1980 \mathrm{~s}$, democratization and human rights concerns gradually replaced the simply strategic-security concerns in the EC/EU's attitudes towards third parties. The evolution of the EU's identity into more political forms has had an impact on the EC accession processes of three Mediterranean countries, namely Greece, Spain and Portugal. 
Unfortunately, Turkey failed to detect these changes in the EC/EU's identity and continued to see its 'Europeanization' process as operating on economic and security levels. The Europeanization strategy of the late President Turgut Ozal during much of the 1980s was based on an economic logic. An accession strategy based on more trade relations with the EU countries, Turkey's adoption of the EU's trade regulations and Turkey's hard-core security co-operation with the EU members were all assumed to eliminate the major obstacles on Turkey's journey to Brussels. In sum, in the absence of the EU's involvement in Turkey's domestic politics as a democratizing agent, Turkey could easily streamline her foreign policy interests with those of the European powers and follow Europe-oriented policies.

\section{The Post-Cold War Era}

Since the cold war ended, it has gradually become more difficult to draw the boundary lines between the democratization process per se and the democratization alongside the EU accession process, as the EU has found itself in a unique position to impose its understanding of democracy on Turkey given Turkey's growing penchant for membership of the EU. ${ }^{1}$ As the EU has increasingly become a significant actor in Turkey's democratization efforts, the way it has interfered in Turkish politics and the way Turkey's state elites have interpreted such EU actions have all shaped the way Turkey has formulated its foreign policies.

The main dilemma for observers in the 1990s was now how to explain certain increasingly anti-EU oriented Turkish foreign policies abroad, particularly those concerning the Cyprus and ESDP disputes, despite the increasing quality of democracy within the country. The transitional democracy model would expect such nationalistic and unilateral policies, first, to take place independently of the EU's role and within the context of the legitimacy claims of the Kemalist state elites, and then to last only briefly.

However, it is argued here that Turkey's anti-EU foreign policy outcomes can be better explained by the context in which her democratization process had to unfold along the Europeanization process in the 1990s. There are two main reasons for this. The first is that the ambiguous EU attitude towards Turkey's accession to the club strengthened the hand of the traditional elites in convincing a great part of Turkish society of the idea that further democratization without strong EU promises of membership would eventually create serious threats to the main premises of republican Turkey, namely secularism and nationalism. Given that the bulk of Turkey's traditional state elites have advocated Turkey's EU 
membership, there were initially no reasons to assume that they would adopt strictly anti-EU oriented foreign policies. However, so long as the EU had not made up its mind about Turkey's membership while demanding that she democratize, these traditional elites could find a legitimate excuse to interpret the democratization along the EU accession process as a threatgenerating exercise. Therefore, they could easily sign up to anti-EU oriented foreign policies.

Until 1999, the extent of suspicion on the part of the two sides was so high that neither of them felt committed to the other. The main rationale in Turkey was that the more the EU felt committed to Turkish accession, the more Turkey could become a democracy and follow pro-EU foreign policies. Since the confirmation of Turkey's candidacy in 1999, the degree of suspicion on both sides has gradually decreased. This has consequently sown the seeds for a new rationale in Turkey, according to which the more Turkey becomes democratized, the more likely it is that the EU would become receptive to Turkish membership.

The second reason is that EU doubts about Turkey's incorporation into the club have consequently prevented her from channelling strong support to the pro-democracy forces within the country. Meanwhile, the way in which the EU has co-operated with such groups has reinforced the suspicions of the state elites regarding the EU's true intentions on Turkey.

The general quality of EU-Turkey relations deteriorated in the 1990s, which in turn helped create the mental background through which democratization along the EU accession process has been perceived as threatening, despite the signing of a customs union agreement in 1995 and the confirmation of Turkey's official EU candidacy in December 1999. While the customs union agreement prompted the majority of the Kemalist elites to perceive Turkey's Europeanization process as operating on trade and economic levels that would in the end bring Turkey one step closer to full membership of such a homo-economicus EU, the majority of the EU members saw it as a mechanism that would keep Turkey in the EU orbit and pave the way for a more functional relationship with Turkey based on closer economic co-operation.

Paradoxically, the way Turkey was accepted as a formal EU candidate at Helsinki in 1999 made it clear that the EU was not determined to offer Turkey a credible membership prospect. The way Turkey accepted the Helsinki decisions and the logic the EU has used in offering candidacy have once again highlighted the instrumental relationship between the parties. Initially, the elimination of the PKK (Partiya Karkeren Kurdistan Kurdistan Workers' Party) threat in early 1999 and the increasing need on the part of Turkey to align with the EU contributed to Turkey's acceptance of the Helsinki decisions. ${ }^{2}$ However, the ruling coalition government of 
the day (headed by the veteran Ecevit), along with the state elites, did hesitate before signing the document, fearing that Turkey's hand against Greece would be weakened. This was evidence of a certain Turkish cynicism towards the EU. On the other hand, it seems that the EU has acted on an instrumental logic, hoping that if Turkey were assured of membership candidacy, she would certainly become more co-operative, implying endorsement of EU policies in relation to the Cyprus and ESDP disputes. Turkey's intransigent behaviour over these issues would make it difficult for the EU to successfully achieve its twin processes of widening and deepening [Nicolaïdis, 2001: 245-77]. Added to this instrumental/insincere EU attitude towards Turkey were the facts both that Turkey has not been incorporated into the emerging ESDP mechanisms, at least not on the basis of the WEU (Western European Union) arrangements for the associate members, and that the EU declined to include Turkey in many of the transEuropean networks that have played significant roles in the EU accession processes of the Central and Eastern European countries.

The Helsinki decisions mainly took place when the majority of EU members concurred that Turkey's de-Europeanization since 1997 could seriously damage the EU's efforts to deal with the globalized and transnationalized security threats and risks emanating from the southern peripheries of the continent. If Turkey's non-European foreign policies continued, as was demonstrated during the 1998 crises over the PKK with Syria and over S-300 missiles with the Greeks/Greek Cypriots, ${ }^{3}$ the EU's efforts to turn itself into a credible security actor might have failed, in the eastern Mediterranean region in particular.

It was within such an atmosphere that Turkey first adopted its National Programme in March 2001 and has since enacted six consecutive reform packages so far, the most significant of them in August 2002. For example, the death penalty has been lifted and Turkish citizens of Kurdish origin have been allowed to use their mother tongue in the field of education. Moreover, Turkey has increased its efforts to reach a settlement with the EU over the ESDP issue and to contribute to the solution of the Cyprus dispute by use of the UN (United Nations) mechanisms. These steps have certainly bolstered Turkey's democratic identity and brought her closer to the European norms.

Despite this positive spiral in EU-Turkey relations since 1999, the EU refused to set a specific date at its Copenhagen Council in December 2002 for the start of accession talks with Turkey. It has decided to let the Republic of Cyprus join the EU by May 2004 even though the parties on the island could not yet reach a political settlement. If the EU does not reverse its stance and offer Turkey a realistic membership prospect soon, the traditional elite will likely interpret the latest democratization openings of the current Justice and Development Party government as threatening 
Turkey's security interests. In such circumstances, Turkey's EU-oriented foreign polices would most likely not be sustained.

Given that the EU's post cold war attitude towards Turkey's accession process has been mainly doubting in nature, it becomes quite important to understand how the ongoing domestic debate between pro-EU and Eurosceptic circles in Turkey would affect Turkey's democratization along the EU accession process on the one hand and the tone of Turkish foreign policies on the other.

\section{Two Discourses}

Within this context, it is important to compare the Eurosceptic and pro-EU circles in Turkey in terms of their perceptions of Turkey's democratization along the EU accession process. To what extent do they think that Turkish foreign policy outcomes should be independent of this process?

One must certainly take into account which of these circles rules in Ankara, if one really wants to make a true analysis of Turkey's foreign policy stances. Even though it is now commonplace to depict these two groups as diametrically opposed to one another and to ascribe all EUoriented Turkish policies to the relative influence of the pro-EU circles in Turkey, it would be unfair to designate the Eurosceptic circles in Turkey as responsible for all the non-European policies. Therefore, it is suggested here that one should mention some fundamental points around which these two circles converge. Before doing this, it would be appropriate to point out that both the pro-EU and Eurosceptic circles favour Turkey's EU membership, though their logics rest on different rationales. They constitute the majority of the political forces in Turkey. One should not fall into the trap of believing that Eurosceptics are totally against Turkey's EU membership as some of the political figures on the Far Right appear to be.

First, both subscribe to the view that the process of democratization has been intermingled with the process of Europeanization. It is now increasingly difficult to ever think of the possibility that Turkey might be trying to democratize while the EU is denying her a strong prospect of membership.

Second, they share the view that democratization would be the most appropriate course of action for the state in order to be able to deal with the transnationalized and multifaceted security threats of the post cold war era [Bazoglu-Sezer, 1992: 227-37; Kibaroglu, 2003]. They agree that a more democratic state-society structure would be better able to deliver peace, prosperity, welfare and a harmonious domestic structure.

Third, they share a common dilemma: how to strike a balance between Turkey's growing penchant for EU membership and the EU's growing 
reluctance to admit Turkey in the near future. Both have been distressed by the prospect that the ambiguity over the true intentions of the EU members on Turkey might paralyse the success of democratization and Europeanization processes in Turkey. The main reason for this is their common scepticism: what if the EU does not agree to Turkey's accession to the club even though Turkey has undertaken all the radical reforms on the way to a liberal-pluralist democracy, as part of the general efforts to comply with the accession criteria [Manisal1, 2001].

Finally, both Eurosceptic and pro-EU circles in Turkey have gradually come to view the modern EU as something radically different to the EC of the cold war years. To both, the new EU is more supranational, more postsovereign, more post-modern, more multicultural and more demanding. It demands of the candidate countries that they undergo a radical transformation process on the basis of the above-mentioned principles and adopt the whole body of Community law in earnest. It asks them to organize their domestic and foreign policies on the premises of liberal-pluralistic democracy. It has a power of attraction stemming from its normative ability to determine the confines of appropriate state behaviour in the European theatre [Christou, 2002; Manners, 2002: 235-58]. However, for the positive and identity-transforming effects of the EU's 'power of attraction' to take place, the conditionality policy of the EU should be credible and backed up with detailed packages of rewards and punishments.

\section{The Eurosceptics}

This category traditionally comprises the Turkish armed forces, the high level bureaucrats in the state apparatus and some conservative political figures in right-of-centre parties. These people are not opposed to Turkey joining the EU but are inclined to interpret the democratization along the EU accession process as potentially threatening if the EU does not offer realistic timetables for Turkey's accession. They have also developed the idea that since the EU has been so reluctant over Turkish membership, democratization might provide the EU with a lever to weaken Turkey and possibly pave the way for the country's disintegration in the face of increasing Kurdish and Islamist claims [Özdağ, 2002].

In general, they are content with Turkey's integration with the EU but problematize the unequal and hierarchical characteristics of the EU accession process [Kopecky and Mude, 2002: 297-326]. They want to bargain with the EU over the terms of the accession criteria, rather than strictly comply with the EU's instructions.

Traditionally these circles have been inclined to think that Turkey, as a sovereign nation-state, should be capable of formulating and implementing its foreign policies independently of the external environment, of which 
the EU is the most important domain. To them, a European-oriented foreign policy should only be followed so long as it serves Turkey's national security interests as usually defined by the Turkish armed forces. Democratization along the EU accession process should not automatically include Turkish foreign policy outcomes being in total harmony with the foreign policies of the EU.

To them, the major EU summit decisions - Luxembourg in 1997, Helsinki in 1999 and Copenhagen in 2002 - have not been encouraging enough to give Turkey an incentive to continue the democratization along the EU accession process. To them further democratization and EU-oriented foreign policies should follow a strong EU commitment towards Turkish membership.

These circles believe that the EU has been discriminating against Turkey on cultural, political and economic grounds. They point to the EU's treatment of the Central and Eastern European countries as evidence. Turkey has neither been given significant sums of financial aid nor incorporated into many of the trans-European network programmes [Rumford, 2000: 331-43]. If this situation goes unaltered, the danger would be great because after all Turkey might be left in the cold after so many years of making democratization efforts.

\section{Pro-EU Circles}

These people make up the majority of Turkish society, including the political figures located in the centre-right and centre-left parties. Since mid-2001, the Justice and Development Party has also supported Turkish EU membership. Departing from the anti-EU policies of its predecessors, the Welfare and Virtue Parties, the new Justice and Development Party, in government since the elections of November 2002, has undertaken radical reform attempts with a view to bringing Turkey closer to the EU. Though it makes a big difference whether the pro-EU stance of the government rests on tactical or strategic reasons, the fact that the party seems to be adamant about the reformation process constitutes a good reason to include this party in the pro-EU camp [Onis and Keyman, 2003: 95-107; Ozel, 2003: 80-94].

Unlike the Eurosceptics, these people think that Turkey's democratization should not be totally dependent on the quality of her relationship with the EU and that the more Turkey becomes democratized, the more it would be likely that the EU would admit Turkey as a member. To them, the process of democratization does not need to run totally parallel to the process of Europeanization. ${ }^{4}$ It is to the benefit of the Turkish people that the democratization process should proceed quickly. However, these people are of the view that Turkey's EU accession process constitutes the most important and healthiest external dynamic for the ongoing democratization process. 
These people also concur that Turkey's democratization should not only concern Turkey's domestic affairs, in terms of the realignment of political forces, but also her foreign policy behaviour. They suggest that Turkey should not adopt confrontational, intransigent, stubborn and uncompromising attitudes towards foreign policy issues, especially those pertaining to Turkey-EU relations. In this vein, Turkey should not create unbridgeable obstacles over Cyprus and should accept the possibility that a solution might be better reached within the framework of the EU. They have accepted that Cyprus can join the EU so long as she meets all the required conditions. $^{5}$ A clear EU-oriented foreign policy should be followed if Turkey wishes to join the Union.

In regard to the general character of EU-Turkey relations, these people recommend that Turkey should behave in a manner that would demonstrate its sincerity on EU membership. Feeling so suspicious of the future intentions of the EU on Turkey's security does not suit a country that has continuously tried to make its way to Brussels. These people seem to be aware of the fact that the relationship between the EU and Turkey is not symmetrical and balanced and that Turkey, as the weaker party in this interaction process, is the side that should do its homework better in order to qualify for membership. After all, it is Turkey that is knocking on the door of the EU.

The pro-EU circles are of the view that it would be to the benefit of the $\mathrm{EU}$, as well as Turkey, if the latter joins the former. For them, the nature of the ongoing accession process, through its side-effect of democratization, does not denote reluctance of the EU to admit Turkey but on the contrary the Union's determination to prepare Turkey for future membership. In other words, these people think that the EU acts on a very rational basis when it incessantly asks Turkey to democratize further. Why, these people ask, might the EU want to weaken Turkey through a process of democratization that would in the end lead to the decentralization and dismemberment of the country? After all, it would be the EU itself that would have to deal with the risks and threats a disintegrating Turkey would likely pose to the EU's institutional identity. For them the current EU accession criteria are designed to enable the EU to digest a big country like Turkey at some time in the future [Oguzlu, 2003: 51-83].

\section{Cases}

This section explores the main reasons why Turkey so far has not followed an apparently EU-oriented foreign policy in relation to the Cyprus and the ESDP issues. Would the choices of a transitional democracy Turkey have been different from the choices of a Turkey that became democratized along 
the EU accession process? In which ways do these factors have an impact on the style, process and outcome of Turkish foreign policy?

For the time being, it seems that the ongoing democratization process in Turkey, whether it unfolds within the EU framework or not, has had its major impact on the process of Turkish foreign policy. In a general sense, the more democratization has taken root, the more diverse societal and political groups have challenged the primacy of the Kemalist understanding, as well as making, of foreign policy. For instance, it is gradually becoming more difficult for the National Security Council, the Foreign Ministry and the Chief of the General Staff, the traditional actors in the Turkish foreign policy-making process, to have the luxury of being able to ignore what public opinion thinks on foreign policy issues. Today, various business associations, civil society organizations, non-governmental research institutes (think-tanks) and the media all act to influence final foreign policy outcomes.

For instance, it was in such an atmosphere that the Motherland Party leader Mesut Yilmaz could freely question the basics of Turkey's National Security Policy on the occasion of the party congress in August 2001. He levelled harsh criticism at the military by openly questioning the exclusive role of the generals in defining the major security threats the country faces [Cizre, 2003: 213-31]. Besides, the Justice and Development Party government has given some signals that it intends to seriously deconstruct the Kemalist foreign and security policy understanding [Robins, 2003: 547-66].

Regarding the impact of Turkey's democratization along the EU accession process on the style of Turkish foreign policy, one would not be able to offer clear answers, mainly because Turkey's bullying style in regard to the Cyprus and ESDP issues might equally have been caused either by moves by the traditional state elites to secure their power positions within the context of transition to democracy, or by their anger directed towards the EU's ambiguous strategy vis-à-vis Turkey's membership. However, given that the traditional state elites are also in favour of Turkey's EU membership and that the EU has been a party to these issues, it is reasonable to deduce that the perceptions of these circles of the EU's intentions have played a fundamental role in the adoption of Turkey's foreign policy style.

If they sensed that the EU had approached Turkey from an ideational logic, committed to Turkey's membership, rather than an instrumental logic, aimed at cajoling Turkey into making concessions on these issues, they would most probably have adopted a compromising style.

While both models seem to offer satisfying explanations of the process and style dimensions of Turkish foreign policy since the 1990s, the democratization along the EU accession process offers better insights into 
the outcome dimension of Turkish foreign policy. What is important here is the context in which the democratization process has been taking place. We will now proceed to analyse this relationship in terms of Turkey's foreign policy outcomes vis-à-vis the Cyprus and ESDP issues.

\section{Cyprus}

In regard to the Cyprus dispute, the impact of the democratization along the EU accession process appears to be mixed. In terms of process, the record is promising since one has seen the emergence of many societal groups that have challenged the well-established Turkish policy on Cyprus. Both within Turkey and the Turkish Republic of Northern Cyprus (TRNC), many political parties, business associations and civil society organizations have demanded increasingly that Turkey and the TRNC abandon the sceptical view of the EU and of the accession of the island to the EU. ${ }^{6}$

Regarding the style, one can claim that the democratization process has had a positive impact in the sense that Turkey has agreed to the continuation of inter-communal talks on the island under the auspices of the UN Secretary General, despite strong reservations concerning the role of the EU [Barkey, 2003: 229-40]. Today, there is a general understanding among Turkish elites that this problem has been Europeanized to a great extent, thanks to Greek efforts, and that Turkey would need to reach acceptable compromises with the Greeks/Greek Cypriots and the Europeans should she aspire to join the EU. However, the fact that Turkey still tends to index her behaviour on Cyprus to the quality/nature of its overall relationship with the EU makes Turkey's style appear as non-European and bullying. Whenever bilateral EU-Turkey relations have turned sour, Turkey has not hesitated to stall the inter-communal talks by depriving the leader of the TRNC, Rauf Denktas, of the support and encouragement he needed. Turkey has also threatened the EU that it might annex the TRNC if the island were to join the EU before a resolution of the dispute [Bagci, 1999: 39-50].

In terms of content, one could certainly claim that Turkey has not behaved as a European country. By trying to index both the resolution of the dispute and the EU membership of Cyprus to the dynamics of its own relations with the EU, Turkey has maintained a very unilateral nationalistic stance. That the people in charge of formulating Turkey's foreign policy have been mainly Eurosceptic in nature affected Turkey's stance on Cyprus radically. These people have generally tended to interpret the EU's involvement in the Cyprus dispute as threatening because Turkey's strategic control over the eastern Mediterranean region in general and the island in particular might be eroded if the island became an EU member before Turkey. The Kemalist state elites have deemed the Cyprus dispute to lie within the realm of Turkish national interests and therefore have adopted 
a cynical attitude towards the involvement of foreign and some domestic circles in the resolution of the dispute [Dodd, 1999: 128-47; Tank, 2002: 146-64; Suvarierol, 2003: 55-78].

Following the EU's Luxembourg summit, where Turkey was excluded from the next group of countries the EU would admit, Turkey's nonEuropean foreign policy has become more visible. Thinking that the EU dealt a strong blow to the quality and nature of EU-Turkey relations, the elites did not hesitate to replace the traditional federalist approach with a much harder line by wholeheartedly supporting the confederalist proposal of the leader of the TRNC. Furthermore, they warned the EU that the more the EU came closer to the Greek Cypriots, as representing the whole island, the more Turkey would speed up the process of integration with the TRNC [Oguzlu, 2002b].

Following the approval of Turkey's formal EU candidacy at Helsinki in 1999 and the EU's Copenhagen summit in December 2002, the impact of democratization along the EU accession process has taken an upward turn. The main reason for this is that the degree of ambiguity in the overall EU-Turkey relations has started to decrease. Turkey has felt the need to tone down its hardline position since UN Secretary General Kofi Annan's proposal of a very detailed solution framework that would both accelerate the speed of inter-communal talks and prepare the way for the smooth accession of the island to the EU [Tocci, 2003: 199-212]. When the Annan plan combined with the Justice and Development Party victory in the last elections, the prospects for Turkey's more EU-oriented foreign policies became clearer because the new government tended to interpret the Copenhagen decision of the EU Council in positive terms. To government circles, this decision was not a blow to the quality of EU-Turkey relations. Despite its shortcomings, if Turkey speeds up the reform process, this particular decision of the EU could pave the way for Turkey's early accession to the EU.

Besides the improvement in the general quality of EU-Turkey relations, one could also mention the following reasons in explaining Turkey's EUoriented policies vis-à-vis the island: the determination of the current government to secure its domestic legitimacy through the EU; the increasing importance of Turkey in the eyes of the Union following 11 September 2001, particularly within the context of deteriorating US-EU relations; the increasing awareness on the part of EU members of the need to turn the Union into a more credible global security actor with vested interests around Turkey's vicinity; and the increasing geopolitical need on the part of Turkey to align with the EU in times of deteriorating US-Turkish strategic-security relations. 
ESDP

In regard to the ESDP dispute, the impact of both the democratization process per se and the democratization alongside the EU accession process on the style, process and outcome dimensions of Turkey's approach to the settlement of the dispute has been minimal, if not negative, in character. Traditional state elites have had a near monopoly on this issue. Due to the 'national issue' character of the ESDP dispute and the concerns about the quality of EU-Turkey relations, the Turkish security elite has approached the issue from a nationalistic and unilateral perspective by adopting a bullying style. These elites have shaped Turkey's choices on their own, without any input from society. Turkey basically did not want the EU to make use of NATO's military capabilities in EU-led military operations unless given satisfactory rights in the decision-making processes of such operations [Missiroli, 2002: 9-26]. Fearing that the EU's Common Foreign and Security Policy initiative would likely jeopardize her rights in European security matters emanating from her full NATO and associate WEU memberships, Turkey has vehemently objected to the EU's efforts to rely on NATO resources while it upgrades its own military capabilities [Orhun, 2000: 115-24].

The fact that Turkey reached an understanding with the EU on the eve of the Leaken summit in late 2001 and again in the margins of the EU's Copenhagen summit in December 2002 does not mean that Turkey's further democratization along the EU accession process has generated this outcome. On the contrary, one can safely argue that this swift change in Turkey's attitude has resulted from the international developments that have taken place since the 11 September 2001 events. Having noticed that the cause of combating global terrorism has once again highlighted Turkey's strategic value to the western international community, particularly the Europeans, Turkish leaders seem to have come to the conclusion that this was the right time for Turkey to strike a deal with the EU. Other additional factors generating this outcome might be the following: the increasing need on the part of the EU members to secure Turkey's co-operation over security issues and the under-performance of the EU in the ESDP process, particularly the failure of the Europeans to increase their military spending and develop a coherent and collective strategic culture.

\section{Conclusion}

This essay has mainly argued that the democratization alongside the EU accession process and the democratization process per se are not the same in the context of Turkey. The former is superior to the latter in the sense that 
the way in which the former unfolds would certainly affect the way in which Turkish elites would perceive the latter. Thought of this way, it has been contended here that Turkey's post cold war foreign policy behaviour in regard to the Cyprus and ESDP issues could be better explained by the nature/quality of overall EU-Turkey relations, particularly as they have unfolded within the context of the EU's increasing calls for democratization in Turkey, rather than the ongoing democratization process per se.

All in all, it would be erroneous to attribute Turkey's apparently anti-EU oriented foreign policies to her transitional democracy identity, for such accounts do not generally take into consideration the environment in which Turkey has found herself in a degraded interaction process with the EU. It is because of this error that some analysts confuse Turkey's democratization process with the ongoing democratization along the EU accession process. Unless this situation is reversed, it will not be possible for analysts to solve the puzzle of why Turkey's foreign policy behaviour became more nonEuropean in the 1990s despite the increasing level of democratization.

\section{NOTES}

1. One can notice the close relationship in various EU reports on Turkey.

2. I wish to thank here one of the anonymous referees.

3. In autumn 1998 high-level Turkish generals and many important political figures openly warned Syria about the repercussions of its continuing support for PKK terrorist activities against Turkey. Implicit in these warnings was a covert reference to the use of force if Syria did not heed Turkey's warnings and stop supporting the PKK. By overtly taking such a stance, Turkey appeared to have diverged from the constitutive norms of the EU's foreign policy-making process, namely de-securitization and multilateral co-ordination. Turkey both securitized its relations with Syria to the highest possible military degree and adopted a unilateral and nationalist strategy in pursuing its goals. Turkey's course of action vis-à-vis the Greek Cypriots and Greece during 1997 and 1998 also testified to Turkey's non-European foreign policy interests and strategies. When the Greek Cypriot government signed a military contract with Russia foreseeing the installation of S-300 surface-to-air (STA) missiles in early 1997 and when Greece supported this Greek Cypriot move as part of its Joint Defence Doctrine, Turkey did not hesitate to issue the harshest possible warning to the Greek side about the consequences if the missiles were brought to the island. Turkey underlined the possibility of using military force to destroy the missiles if it believed that those missiles endangered Turkey's security and significantly curtailed its strategic superiority over the island.

4. Various liberal-oriented opinions on this issue can be found at the Internet site of the Association for Liberal Thinking (Liberal Düpünce Topluluğu) at: <http://liberaldt.org.tr/index.htm>. For example, see İhsan Dağý, 'Ulusal Güvenlik: Kimin Gğüvenliği' [National Security: Whose Security], at <http://liberal-dt.org.tr/at/ihsandagi/at-id3.htm>.

5. The majority of the contributors to the Radikal newspaper in Turkey take this view. See for example the numerous articles by Erdal Guven and Ismet Berkan. The paper can be found at: <http://www.radikal.com.tr>.

6. For example, the majority of Turkish people now think that all the political parties in Cyprus other than those forming the current government and backing President Denktas' stance on the inter-communal talks oppose Turkey's well-established Cyprus policy and argue the merits of joining the EU after reaching a settlement with the Greek Cypriots on the basis of the peace plan of Kofi Annan. 


\section{REFERENCES}

Aybet, G. and M. Müftüler-Baç (2000): 'Transformations in Security and Identity after the Cold War: Turkey's Problematic Relationship with Europe', International Journal 55, pp.567-82.

Bagci, H. (1999): 'Turkish Reactions to the EU Approach', in S. Baier-Allen (ed.), In Looking into the Future of Cyprus-EU Relations, Baden-Baden: Nomos Verlag, pp.39-50.

Barkey, J.H. (2003): 'Cyprus: Between Ankara and A Hard Place', Brown Journal of World Affairs 10/1, pp.229-40.

Bazoglu-Sezer, D. (1992): 'Threat Perceptions in Southern Europe: The Case of Turkey', in L. Valki (ed.), Changing Threat Perceptions and Military Doctrines, London: Macmillan.

Christou, G. (2002): 'The European Union and Cyprus: The Power of Attraction as a Solution to the Cyprus Dispute', Journal on Ethnopolitics and Minority Issues in Europe 2.

Cizre, U. (2003): 'Demythologyzing the National Security Concept: The Case of Turkey', Middle East Journal 57/2, pp.213-31.

Dagi, I. (2001): 'Human Rights and Democratization: Turkish Politics in the European Context', Southeast European and Black Sea Studies 1/3, pp.51-68.

Dodd, C.H. (1999): 'Cyprus in Turkish Politics and Foreign Policy', in C.H. Dodd (ed.), Cyprus: The Need for New Perspectives, Cambridgeshire: Eothen Press.

Flynn, G. and H. Farrell (1999): 'Piecing Together The Democratic Peace: The CSCE, Norms, and the "Construction" of Security in the Post-Cold War Europe', International Organization 53/3, pp.505-36.

Grabbe, H. (2002): 'European Union Conditionality and the Acquis Communautaire', International Political Science Review 23/3, pp.249-68.

Heper, M. (2000): 'The Ottoman Legacy and Turkish Politics', Journal of International Affairs $54 / 1$, pp.63-82.

Iokimidis, P.C. (2000): 'The Europeanization of Greece's Foreign Policy: Progress and Problems', in A. Mitsos and E. Mossialos (eds.), Contemporary Greece and Europe, Aldershot: Ashgate.

Kibaroglu, M. (2003): 'Turkey's Threat Perceptions from the East: A Roadblock in its March toward the West', in A.L. Karaosmanoglu and S. Tashan (eds.), Turkey's Security Perception and the European Union: Compatibilities and Incompatibilities, The Hague: Kluwer.

Kopecky, P and C. Mude (2002): 'The Two Sides of Euroscepticism: Party Positions on European Integration in East Central Europe', European Union Politics 3/3, pp.297-326.

Manisali, E. (2001): İçüzü ve Perde Arkasıyla Avrupe Çıkmazı Türkiye-Avrupa Birliği İlişsileri [The European Impasse in its Essence: Turkey-European Union Relations], Istanbul: Otopsi Yayınları.

Manners, I. (2002): 'Normative Power Europe: A Contradiction in Terms?' Journal of Common Market Studies 40/2, pp.235-58.

Missiroli, A. (2002): 'EU-NATO Cooperation in Crisis Management: No Turkish Delight for ESDP', Security Dialogue 33/1, pp.9-26.

Nicolaïdis, K. (2001): 'Europe's Tainted Mirror: Reflections on Turkey's Candidacy Status after Helsinki', in D. Keridis and C.M. Perry (eds.), Greek-Turkish Relations in the Era of Globalisation, Dulles, VA: Brassey's.

Oguzlu, H.T. (2002a): 'The Clash of Security Identities: The Question of Turkey's Membership in the European Union', International Journal 54/3, pp.579-603.

Oguzlu, H.T. (2002b): 'The EU as an Actor in the Solution of the Cyprus Dispute: The Questions of How?' Journal on Ethnopolitics and Minority Issues in Europe 2.

Oguzlu, H.T. (2003): 'How to Interpret Turkey's Accession Process with the European Union', Perceptions 7/4, pp.51-83.

Olsen, J.P. (2002): 'The Many Faces of Europeanization', Journal of Common Market Studies 40/5, pp.921-52.

Onis, Z. and E. Fuat Keyman (2003): 'A New Path Emerges', Journal of Democracy 14/2, pp.95-107.

Orhun, O. (2000): 'European Security and Defence Identity - Common European Security and Defence Policy: A Turkish Perspective', Perceptions 5/3, pp.115-24. 
Özdağ, U. (2002): Türkiye-Avrupa Birliği İlişkileri Jeopolitik İnceleme [Turkey-European Union Relations: A Geo-political Analysis], Ankara: ASAM Yayınları.

Ozel, S. (2003): 'After The Tsunami', Journal of Democracy 14/2, pp.80-94.

Ray, J.L. (1998): 'Does Democracy Cause Peace?' Annual Review of Political Science 1, pp. $27-46$.

Risse-Kappen, T. (1995): 'Democratic Peace - Warlike Democracies? A Social Constructivist Interpretation of the Liberal Argument', European Journal of International Relations 1/4, pp.491-517.

Robins, P. (2003): 'Confusion at Home, Confusion Abroad: Turkey between Copenhagen and Iraq', International Affairs 79/3, pp.547-66.

Rumford, C. (2000): 'From Luxembourg to Helsinki: Turkey, the Politics of EU Enlargement and Prospects for Accession', Contemporary Politics 6/4, pp.331-43.

Smith, K.E. (2000): 'The Conditional Offer of Membership as an Instrument of EU Foreign Policy: Reshaping Europe in the EU's Image', Marmara Journal of European Studies 8/1-2, pp.33-46.

Suvarierol, S. (2003): 'The Cyprus Obstacle on Turkey's Road to Membership in the European Union', Turkish Studies 4/1, pp.55-78.

Tank, P. (2002): "Re-solving” the Cyprus Problem: Changing Perceptions of State and Societal Security', European Security 11/3, pp.146-64

Tocci, N. (2003): 'Towards Peace in Cyprus: Incentives and Disincentives', Brown Journal of World Affairs 10/1, pp.199-212.

Tsakonas, P. (2001): 'Turkey's Post-Helsinki Turbulence: Implications for Greece and the Cyprus Issue', Turkish Studies 2/2, pp.1-40.

Walker, R.B.J. (1993): Inside/Outside: International Relations as Political Theory, Cambridge: Cambridge University Press.

Wendt, A. (1999): The Social Theory of International Politics, Cambridge: Cambridge University Press. 